\title{
Project-Based Learning in Teaching EFL Writing: An Analysis of the Effect on The 5 Dimensions of Writing
}

\section{Ni Komang Sri Wardani ${ }^{*}$, Luh Putu Artini2 ${ }^{2}$, Dewa Putu Ramendra ${ }^{3}$}

1,2,3 English Language Education Postgraduate Program, Ganesha University of Education, Singaraja, Indonesia

\section{A R T I C L E I N F O}

Article history:

Received January 28, 2021

Revised February 16, 2021

Accepted April 24, 2021

Available online May 25, 2021

Kata Kunci :

Project-Based Learning,

Keterampilan Menulis, 5 Dimensi

Menulis

Keywords:

Project-Baesd Learning, Writing Skill, 5 Dimensions of Writing

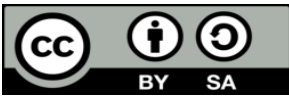

This is an open access article under the CC BY-SA license.

Copyright (C) 2021 by Author. Published y Universitas Pendidikan Ganesh

\section{A B S T R A C T}

\begin{abstract}
A B S T R A K
Pendidikan mulai melihat pentingnya konstruktivisme dalam beberapa tahun terakhir untuk menciptakan strategi belajar/mengajar yang efektif. Ada beberapa model pengajaran yang dibangun berdasarkan teori konstruktivis. Salah satu model tersebut adalah Project Based Learning. Penelitian ini bertujuan untuk menganalisis pengaruh Project Based Learning terhadap keterampilan menulis siswa kelas IX. Penelitian ini mengimplikasikan embedded mixed method design, yaitu data kuantitatif dianggap sebagai data utama. Pengumpulan data dilakukan melalui wawancara terbimbing, observasi, angket terbuka, dan tes menulis. Uji-t sampel berpasangan digunakan untuk menganalisis ada tidaknya perbedaan yang signifikan dalam keterampilan menulis siswa sebelum dan sesudah diajar menggunakan PjBL, dan Manova digunakan untuk menganalisis bagaimana pembelajaran berbasis proyek mempengaruhi keterampilan menulis siswa dalam hal isi, organisasi, struktur, kosa kata, dan mekanik. Sedangkan data kualitatif dianalisis secara deskriptif. Hasil penelitian menunjukkan bahwa Pembelajaran Berbasis Proyek berpengaruh signifikan terhadap keterampilan menulis bahasa Inggris siswa dan juga mempengaruhi keterampilan menulis siswa dalam hal isi, organisasi, struktur, kosa kata, dan mekanik (sig. $=0,000<=0,05$ ). Pembelajaran Berbasis Proyek juga terungkap berpotensi mendorong pemikiran kritis siswa, kreativitas, kerja kolaboratif, dan meningkatkan kepuasan guru dalam mengajar. Secara umum dapat disimpulkan bahwa Pembelajaran Berbasis Proyek secara signifikan meningkatkan keterampilan menulis siswa kelas IX.
\end{abstract}

Education has begun to see important constructivism in recent years to create effective teaching/learning strategies. There are several teaching models which are constructed based on constructivist theory. One of those models is Project-Based Learning. This study aims to analyze the effect of Project-Based Learning on students' writing skill of grade IX students. This study implied embedded mixed method design, in which the quantitative data were considered as the main data. The data were collected through guided interview, observation, openended questionnaire, and writing test. Paired-sample t-test was used to analyze whether or not there is a significant difference in students' writing skill before and after being taught using PBL, and Manova was used to analyze how project-based learning affected students' writing skill in term of content, organization, structure, vocabulary, and mechanic. While the qualitative data were analyzed descriptively. The result showed that ProjectBased Learning has significant effect on students' English writing skill and it also affected the students' writing skill in term of content, organization, structure, vocabulary, and mechanic (sig. $=0.000<\alpha=0.05$ ). Project-Based Learning also revealed potentially promotes students' critical thinking, creativity, collaborative work, and enhances teacher's satisfaction in teaching. In general, it can be concluded that Project-Based Learning significantly improves students' writing skill of the grade IX students.

\section{INTRODUCTION}

Education has begun to see important constructivism in recent years to create effective teaching/learning strategies (Ahmed, 2015; Boholano, 2017). The students create their understanding of the world they live in by reflecting on their own personal experiences and to create their own new understanding on the basis of interaction between what they have already know and what they come into contact (Jumaat et al., 2017; Kizkapan \& Bektas, 2017; Praba et al., 2018). In other words, the students have responsibility for their own learning. There are many constructivist teaching strategies used in the science classes such as project based learning (Devkota et al., 2017; Wongdaeng \& Hajihama, 2018), 5E learning cycle model (Piyayodilokchai et al., 2013; Putra et al., 2018), and inquiry based approaches (Bayram et al., 2013; Hwang et al., 2013).

There are several teaching models which are constructed based on constructivist theory. One of those models is Project-Based Learning (Essien, 2018). In the view of this, Project based Learning (PBL) is 
one of the methods recommended to be used. PBL refers to a method allowing "students to design, plan, and carry out an extended project that produces a publicly exhibited output such as a product, publication, or presentation" (Amante et al., 2010; Ayaz \& Söylemez, 2015). PJBL is the methods that push the student too not only about absorbing the material but the student also has to produce something from the material they understood (Hasani et al., 2017; Kimsesiz, 2017).

PJBL is underpinned by learning theories of constructivism and situated learning theory and is strongly influenced by the ideas espoused by Dewey where 'learning by doing' features (Chikita et al., 2013). By applying project based learning, it automatically will increase the students' creativity. Not only about how this learning model can improve the students' writing skill but also by producing something it will encourage the students creativity which it emphasizes learning through student-centered, interdisciplinary, and integrated activities in real world situation (Ayaz \& Söylemez, 2015; Giri, 2016; Kartikasari, 2018). In such situation, PBL can be a milestone for preparing students as global citizens with knowledge and skills to tackle the problems and issues in 21st century global market. Regarding the potentials of Project-based Learning and the complexity of English achievement, research on this needs to be conducted. Based on the preliminary observation, it was observed that the class interaction was still dominated by only some students. Others tend to be passively listened to the teacher, which indicates that self-directed learning was not achieved by the students. Besides, in the learning process, especially the SMP Negeri 1 Tembuku the teacher taught English passively. The teacher rarely tried alternative model. And also the teacher rarely emphasized on the 5 dimensions of writing, those are content, organization, structure, vocabulary, and mechanic, so it became the weekness of the student's writing skill. This was due to the fact that English was an uninteresting subject for the students especially in writing skill. This study aims to analyze the effect of Project-Based Learning on students' writing skill of grade IX students.

\section{METHODS}

The research methods used in this study can be regarded as a Mixed-method Design. Mixed method design focuses on collecting, analyzing, and mixing both quantitative and qualitative data which are taken at grade 9 students' of SMP Negeri 1 Tembuku. In this present study, the researcher purposes different research questions (qualitative and quantitative data) and collect both data during a single study. The quantitative data are more effective on measuring outcomes of experiment (Creswell, 2012). Besides, qualitative data are used to identify the experiences of the participant in the process. Among the major types of mixed-method, embedded design was considered to be the most appropriate design for the present study. An embedded mixed-method design involves the collection of both quantitative and qualitative data, but one of the data types plays a supplemental role within the overall design (Fraenkel \& Wallen, 1993). Technically, this design was beneficial when a researcher needs to embed a qualitative component within a quantitative design or vice versa.

Quantitative data were obtained from pre-test and post-test. The pre-test, post-test was implemented through online learning in the form of Google Classroom. They played major role to provide information about the extent by which project-based learning affects students'writing skill. The qualitative data in this study are collected before, during, and after collecting quantitative data currently. In observing the process of teaching and learning EFL and writing product, it collected from open-ended questionnaire, observation checklist and interview. Essentially, it is used to support and provide further elaboration related to the result of quantitative data. Technically, the qualitative data will be taken into account to provide a deeper understanding on students' feedback toward English Language Learning. Eventually, the data mixing is done only at the interpretation stage to ensure triangulation of the data sources.

\section{RESULT AND DISCUSSION}

\section{Results}

\section{The Effect of Project-Based Learning on Students' Writing Skill}

To answer the first research question, paired-sample t-test was used to compare between the writing scores from pre-test and post-test. Pre-test was administered to obtain preliminary data at the beginning of the study before the treatment was conducted. Then, post-test was carried out to investigate the effect of Project-based Learning on students' writing skill. The result of the writing pre-test and posttest can be seen in the Table 1. 
Table 1. Frequency of Writing Test

\begin{tabular}{cccc}
\hline Data & Mean Score & Below the Mean Score & Above the Mean Score \\
\hline Pre-Test & 68.13 & 21 & 9 \\
Post-Test & 80.80 & 18 & 12 \\
\hline
\end{tabular}

In order to find out the students' writing skill, the pre-test of writing skill was administered in class IX D. There were 30 students who participated in this activity. From the pre-test, it was revealed that the mean score was 68.13 . From 30 students, there were only 9 students (30\%) who had score above the mean score. Meanwhile, the other 21 (70\%) achieved under mean score. It means that more than half of the students in IX D were having score below the mean score. Furthermore, according to result of writing post-test, it was obtained that the mean score of the writing was higher than in the pre-test. Moreover, from 30 students there were 12 students (40\%) who got score above the mean score. Meanwhile, the rest of 18 students (60\%) got score below the mean score. In this study, the normality test was taken to find out whether the obtained data distributed normally or not. This test was administered by KolmogorovSmirnov formula by using IBM SPSS 22. The data are considered as normally distributed if the significant result is more than 0.05. For pre-test writing, the value of Kolmogorov-Smirnov statistic was 1.140 with significance score of 0.149 . Moreover, post-test writing, the value of Kolmogorov-Smirnov statistic was 0.918 with significance score of 0.368 . Those statistic data showed that the significance of the statistic was higher than 0.05 , which can be said that the data were normally distributed. Normality test was followed by the parametric test. Since the data were normally distributed, a paired-samples t-test was applied. The data are considered to have significant effect if the significant score is less than 0.05 . The result of the data showed that there was an improvement of students' writing test between pre-test and post-test. On the pre-test the mean score was 68.13 , meanwhile on the post-test it was 80.80 . Furthermore, the analysis results show that the significance value of the effect of Project-Based Learning on students' writing skill was 0.000 , while the standard of significant is 0.05. It means that there was a significant effect of ProjectBased Learning on students' writing skill.

\section{Project-Based Learning Affected Students' Writing Skill in term of Content, Organization, Structure, Vocabulary, and Mechanic}

The second hypothesis in this study was analyzed by using MANOVA which was different with the previous hypothesis in terms of the analyzing technique. This third hypothesis was focus on the dependent variables which were the 5 dimensions of writing (content, organization, structure, vocabulary, and mechanic). The formula of the second hypothesis was How does project-based learning affect students' writing skill in term of content, organization, structure, vocabulary, and mechanic. The data that analyzed second hypothesis can be seen on several tables, which can be presented in Table 2 .

Table 2. The Results of Multivariate Test

\begin{tabular}{lcc}
\hline \multicolumn{1}{c}{ Effect } & F & Sig \\
\hline Pillai's Trace & $26.092^{\mathrm{a}}$ & 0.000 \\
Wilks' Lambda & $26.092^{\mathrm{a}}$ & 0.000 \\
Hotelling Trace & $26.092^{\mathrm{a}}$ & 0.000 \\
Roy's Largest Root & $26.092^{\mathrm{a}}$ & 0.000 \\
\hline
\end{tabular}

The data gained by statistical score of Pillai's Trace, Wilks' Lambda, Hotelling's Trace and Roy's Largest Root on the table above. The score of $F$ for each statistical is 26,092 with a significance level of 0.000 . It shows that $\mathrm{p}<0.05$. and $\mathrm{H}_{\mathrm{a}}$ was accepted. It implies that there was a significant effect of the 5 dimensions of writing. It means that project-based learning affected students writing skill on the 5 dimensions of writing. Furthermore, there is another result of the second hypothesis testing can be presented in Table 3.

Table 3. The result of the Tests of Between-Subjects Effects

\begin{tabular}{cccccc}
\hline Component & Test & Mean & F & Sig & $\mathbf{R}^{2}$ \\
\hline \multirow{2}{*}{ Content } & Pre & 3.867 & \multirow{2}{*}{0.374} & 0.003 & 0.110 \\
& Post & 3.733 & & & 0.425 \\
\hline
\end{tabular}




\begin{tabular}{cccccc}
\hline Component & Test & Mean & F & Sig & $\mathbf{R}^{2}$ \\
\hline & Post & 4.067 & & & \\
Vocabulary & Pre & 3.467 & 27.757 & 0.000 & 0.312 \\
& Post & 4.300 & & & \\
Grammar & Pre & 3.067 & 40.031 & 0.000 & 0.398 \\
& Post & 4.067 & & & \\
Mechanic & Pre & 3.433 & 12.871 & 0.000 & 0.168 \\
\hline
\end{tabular}

Based on the types of the Tests of Between-Subjects Effects, the results of the analysis showed that the Project-Based Learning method has a significant effect on the 5 dimensions of writing. Firstly, Project-Based Learning method has a significant effect on the content component, the score of $\mathrm{F}$ was 10,374 with a significance level of 0.003 . It shows that $p<0.05$. Secondly, Project-Based Learning method has a significant effect on the organization component, the score of $F$ was 44,555with a significance level of 0.000 . It shows that $p<0.05$. Thirdly, Project-Based Learning method has a significant effect on the vocabulary component, the score of $F$ was 27,757 with a significance level of 0.000 . It shows that $p<0.05$. Fourthly, Project-Based Learning method has a significant effect on the grammar component, the score of $\mathrm{F}$ was 40,031 with a significance level of 0.000 . It shows that $\mathrm{p}<0.05$. The last, Project-Based Learning method has a significant effect on the mechanic component, the score of $\mathrm{F}$ was 12,871 with a significance level of 0.000 . It shows that $\mathrm{p}<0.05$. Project-Based Learning's contribution to the content component was $11 \%$, the organization component was $42.5 \%$, the vocabulary component was $31.2 \%$, the grammar component was $39.8 \%$, and the mechanic component was $16.8 \%$, thus it can be concluded that ProjectBased Learning affected students writing skill on the 5 dimensions of writing. From those data, ProjectBased Learning greatly affected the organization component, because it has the largest contribution.

\section{The Effect of Project-Based Learning on the Teaching and Learning Process}

In order to answer the third research question about how Project-Based Instruction influences the teaching and learning process, the data are described in two sets. First, the data described from the observation checklist. Second, the data gained from the students' perspective from the open-ended questionnaire. Based on the findings on observation and open-ended questionnaire, the influence of Project-Based Learning on teaching and learning process can be seen from several aspects which described as follows.

\section{Collaboration in the Implementation of Project-Based Learning}

As the essence of Project-based Learning, which is collaborative learning, the students were required to work in group of three. Because of the Covid-19 pandemic, the teacher asked the students to make a group based on the closest house and all the students live around SMP 1 Tembuku. The students asked to make a group consist of 3 students. Each group was given some examples of texts which were going to discussed through Google Classroom. Then, the students were instructed to discuss in group and identified text. In the process of the discussion, the researcher helped and monitored the students through WhatsApp Group. From the observation, it was found that the students gave their positive feedback toward the teaching and learning process conducted based on Project Based Learning. They involved well in the group discussion and started to manage the person in charge in group to do the project. In Projectbased Learning, the students were also required to construct Project Timeline with the group. This timeline consists of the activities and the days that the students need to plan first before doing the project. The activities included starting from collecting the materials for the contents until evaluation of the project. Students collaboration in make project timeline with their group was presented in Figure 1.

\section{Project-Based Learning Enhances Students' Creativity}

In this study, Project-Based Learning was also found effective in enhancing students' creativity. The students were trained to have a higher thinking habit that required them to think beyond their conventional way. The students were able to bring up their ideas in constructing the projects. They were also able to develop some thinking without being judge by the teacher. It clearly promoted students' hidden ability in thinking. The previous findings were also supported by Figure 2. Figure 3 represent the students' project result. By seeing the students' product, it can be assumed that students were engaged with sets of activities. Those activities were promoting students' creativity in finishing their project. It was also supported by the observation findings which revealed students' improvement in the process of creating the project. It was found that students were able to use other kind of resource, such as internet, 
magazine, newspaper etc.

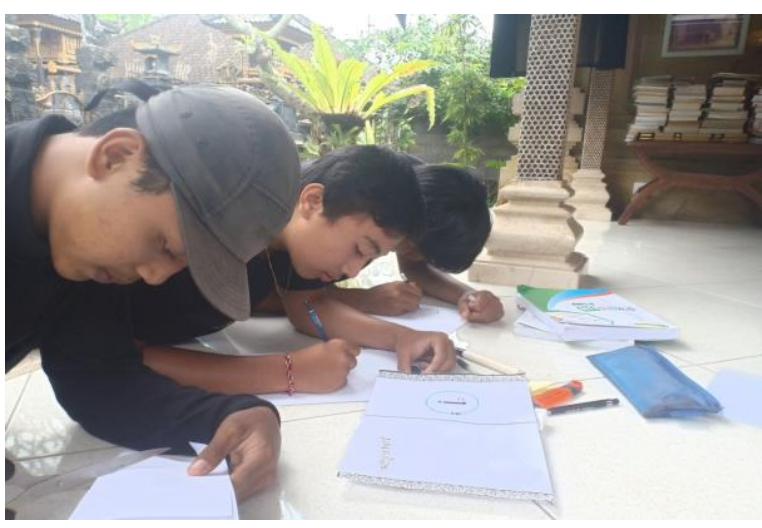

Figure 1. Students collaborate to make project timeline with their group

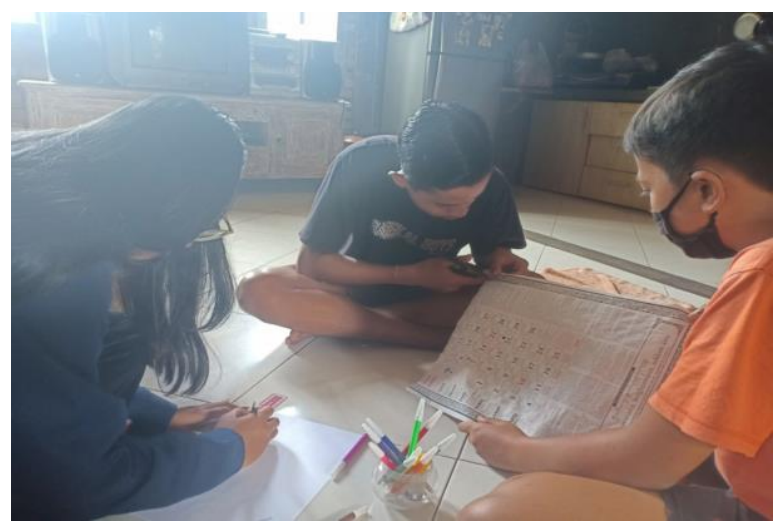

Figure 2. Students decorate their project with their own creativity

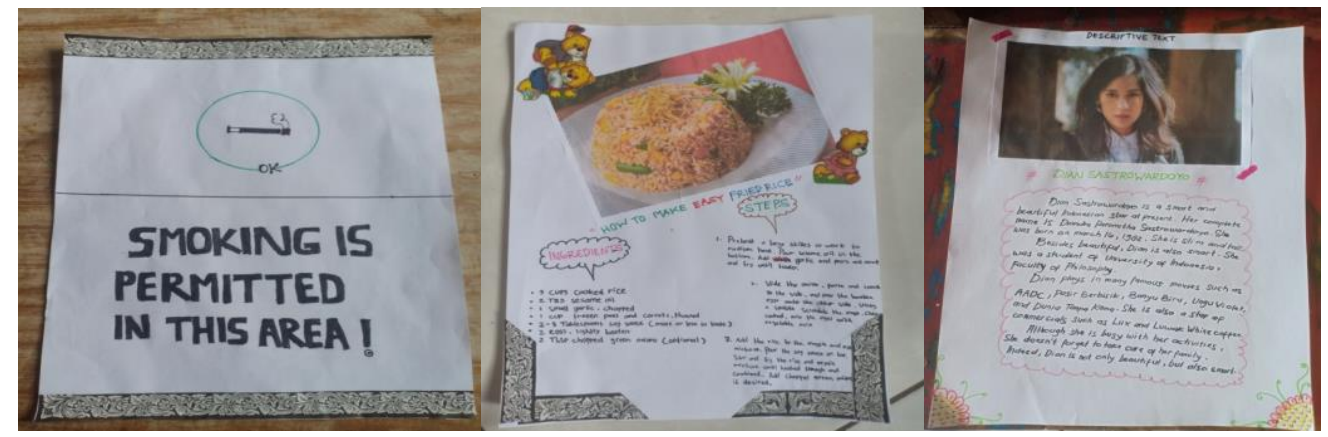

Figure 3. The Students' Final Project

\section{Critical Thinking and Problem Solving Practice through Project-Based Learning}

Data gained for this research focus in using classroom observation and open-ended questionnaire. From the observation, it was found that the students actively responded to the guiding questions before they do the project. The students were required to respond to some guiding/essential questions which guided them to do the project. For example, the guiding/essential questions in the first project involves (1) Have you seen this picture before? (2) Where can you find this? (3) What is the function of this sign? (4) What should you do if you see this sign? (5) Is this belong to command or prohibition? When the guiding questions are stated, the students started thinking and tried to give their opinions and related with their own experiences. Thus, through the implementation of Project-based Learning, the students are taught to be critically in thinking that will lead them to correct solution in coping their own matters. The critical thinking learning is given through online class discussion which is integrated to the subject learned. The problems were then discussed in-group discussions, which consist of three students. The discussions were expected to produce a product from the students. The discussion itself was aimed to identify the concept and to plan the design of the product.

\section{Project-Based Learning Enhances Teacher's Satisfaction in Teaching}

Moreover, Project-Based Learning was also found to be effective in enhancing teacher's satisfaction in teaching. By allowing teacher to teach in more satisfying way, it could improve teaching and learning quality. Similarly, as previous finding, the students' positive responses on learning activities are the key of teacher's satisfaction. After being taught by using Project-Based Learning, the students responded to learning positively. That factor was involved in teacher's teaching satisfaction. By using project in teaching the knowledge, it allowed teacher to teach in more convincing way. The teacher is also given chance to develop teaching skill in preparing the lesson. It can be assumed that by implementing Project-Based Learning, the teacher's satisfaction in teaching was increased.

\section{Discussion}

In finding out the impact of Project-Based Learning on students' writing skill, paired sample t-test was applied. The writing pre and post-test showed result of paired sample t-test with the value of $t=-$ 
$11.483, \mathrm{P}=.000$. The significance score of this statistic was less than the significance level which was 0.05 (sig. $=0.00<\alpha=0.05$ ). Based on this result, it can be concluded that there was significant impact of Project-Based Learning on students 'writing skills. Furthermore, to answer the second research question about Project-Based Learning affected students' writing skill in term of content, organization, structure, vocabulary, and mechanic, Manova was also applied. Based on the types of Multivariate statistic, the results of the analysis showed that the result of F to Pillai's Trace, Wilks' Lambda, Hotteling's Trace, Roy's Largest Root has counted as F on 26,092 with significant of 0.000. It can be said that, the result of F to Pillai's Trace, Wilks' Lambda, Hotteling's Trace, Roy's Largest Root were all significant, since the significant score was less than 0.05 . Therefore, it can be stated that, there was a significant effect of the 5 dimensions of writing. Those 5 dimensions are content, oeganization, structure, vocabulary, and mechanic.

Refarding to the types of the Tests of Between-Subjects Effects, the results of the analysis showed that the Project-Based Learning method has a significant effect on the 5 dimensions of writing. Firstly, Project-Based Learning method has a significant effect on the content component, the score of $\mathrm{F}$ was 10,374 with a significance level of 0.003 . Secondly, Project-Based Learning method has a significant effect on the organization component, the score of $\mathrm{F}$ was 44,555 with a significance level of 0.000 . Thirdly, Project-Based Learning method has a significant effect on the vocabulary component, the score of $\mathrm{F}$ was 27,757 with a significance level of 0.000 . Fourthly, Project-Based Learning method has a significant effect on the grammar component, the score of $\mathrm{F}$ was 40,031 with a significance level of 0.000 . The last, ProjectBased Learning method has a significant effect on the mechanic component, the score of $F$ was 12,871with a significance level of 0.000 . All components shows that $p<0.05$.

Project-Based Learning's contribution to the content component was $11 \%$, the organization component was $42.5 \%$, the vocabulary component was $31.2 \%$, the grammar component was $39.8 \%$, and the mechanic component was $16.8 \%$, thus it can be concluded that Project-Based Learning affected students writing skill on the 5 dimensions of writing. From the data above, showed that Project-Based Learning greatly affected the organization component, because it has the largest contribution. In order to answer the third research question, the observation was done during the implementation of Project-Based Learning in the classroom. During the treatment, it can be observed that the students gave their positive feedback toward the teaching and learning process conducted based on Project-Based Learning. The projects are done through investigative activities in which students can use their critical thinking, creativity, collaborative ability, decision making, and problem-solving skills.

PJBL is underpinned by learning theories of constructivism and situated learning theory and is strongly influenced by the ideas espoused by Dewey where 'learning by doing' features (Chikita et al., 2013). By applying project-based learning, it automatically will increase the students' creativity. Not only about how this learning model can improve the students' writing skill but also by producing something it will encourage the students creativity which it emphasizes learning through student-centered, interdisciplinary, and integrated activities in real world situation (Ayaz \& Söylemez, 2015; Giri, 2016; Kartikasari, 2018). In such situation, PBL can be a milestone for preparing students as global citizens with knowledge and skills to tackle the problems and issues in 21st century global market. Regarding the potentials of Project-based Learning and the complexity of English achievement, research on this needs to be conducted.

\section{CONCLUSION}

Based on data findings and discussion explained in this research, it can be concluded that ProjectBased Learning has a significant impact on students writing Skill of the ninth grade students. ProjectBased Learning affected Students 'Writing Skill in terms of content, organization, structure, vocabulary, and mechanic of the grade 9 students. Project-Based Learning is an effective instructional method for enhancing the quality of students 'learning in terms of critical thinking, communication, collaboration and creativity. It encourages students to be more active, increasing collaboration, succeeds in solving and complex problems.

\section{REFERENCES}

Ahmed, S. (2015). Attitudes towards English Language Learning among EFL Learners at UMSKAL. Journal of Education and Practice, 6(18), 6-16. https://eric.ed.gov/?id=EJ1079681.

Amante, B., Lacayo, A., Pique, M., Oliver, S., Ponsa, P., \& Vilanova, R. (2010). Evaluation of methodology PBL done by students. 2010 IEEE Transforming Engineering Education: Creating Interdisciplinary Skills 

for
Complex
Global
Environments,
1-21.

https: //ieeexplore.ieee.org/abstract/document/5508811/.

Ayaz, M. F., \& Söylemez, M. (2015). The Effect of the Project-Based Learning Approach on the Academic Achievements of the Students in Science Classes in Turkey: A Meta-Analysis Study. Education \& Science/Egitim Ve Bilim, 40, 178.

Bayram, Z., Oskay, Ö. Ö., Erdem, E., Özgür, S. D., \& Şen, Ş. (2013). Effect of Inquiry based Learning Method on Students' Motivation. Procedia - Social and Behavioral Sciences, 106, 988-996. https://doi.org/10.1016/j.sbspro.2013.12.112.

Boholano, H. (2017). Smart social networking: 21st century teaching and learning skills. Research in Pedagogy, 7(1), 21-29. https://www.ceeol.com/search/article-detail?id=546738.

Chikita, G. P., Padmadewi, N. N., \& Suarnajaya, I. W. (2013). The Effect Of Project Based Learning And Students'perceived Learning Discipline Toward The Writing Competency Of The Eleventh Grade Students Of Sman 5 Mataram In The Academic Year 2012/2013. Jurnal Pendidikan Bahasa Inggris Indonesia, 1(1). https://ejournal-pasca.undiksha.ac.id/index.php/jpbi/article/view/747.

Creswell, J. W. (2012). Educational Research: Planning, Conducting and Evaluating Quantitative and Qualitative Research. University of Nebraska-Lincoln: Pearson.

Devkota, S. P., Giri, D. R., \& Bagale, S. (2017). Developing 21st century skills through project-based learning in EFL context: challenges and opportunities. The Online Journal of New Horizons in Education, 7(1), 47-52. $\quad$ http://www.tojdel.net/journals/tojned/volumes/tojned-volume07i01.pdf\#page $=54$.

Essien, A. M. (2018). The effects of project-based learning on students' English language ability. The 2018 International Academic Research Conference, Vienna.

Fraenkel, J. R., \& Wallen, N. E. (1993). How to Design and Evaluate Research in Education (2nd ed.). Mc. Graw-Hill.

Giri, D. R. (2016). Project-based learning as 21st century teaching approach: A Study in Nepalese Private Schools. US-China Education Review A, 6(8), 487-497.

Hasani, A., Hendrayana, A., \& Senjaya, A. (2017). Using Project-Based Learning in Writing an Educational Article: An Experience Report. Universal Journal of Educational Research, 5(6), 960-964. https://eric.ed.gov/?id=EJ1143913.

Hwang, G. J., Wu, P. H., Zhuang, Y. Y., \& Huang, Y. M. (2013). Effects of the inquiry-based mobile learning model on the cognitive load and learning achievement of students. Interactive Learning Environments, 21(4), 338-354. https://doi.org/10.1080/10494820.2011.575789.

Jumaat, N. F., Tasir, Z., Halim, N. D. A., \& Ashari, Z. M. (2017). Project-based learning from constructivism point of view. Advanced Science Letters, 23(8), 7904-7906. https://doi.org/10.1166/asl.2017.9605.

Kartikasari, N. (2018). The Implementation of Project Based Learning by Making Vlog in Teaching Speaking of Recount Text for Junior High School. RETAIN, 6(3). https: //ejournal.unesa.ac.id/index.php/retain/article/view/26154.

Kimsesiz, F. (2017). The Effect of Project Based Learning in Teaching EFL Vocabulary to Young Learners of English: The Case of Pre-School Children. Online Submission, 5(4), 426-439. https: //eric.ed.gov/?id=ED581572.

Kizkapan, O., \& Bektas, O. (2017). The effect of project based learning on seventh grade students' academic achievement. In International Journal of Instruction (Vol. 10, Issue 1, pp. 37-54). https://doi.org/10.12973/iji.2017.1013a.

Piyayodilokchai, H., Panjaburee, P., Laosinchai, P., Ketpichainarong, W., \& Ruenwongsa, P. (2013). A 5E Learning Cycle Approach-Based, Multimedia-Supplemented Instructional Unit for Structured Query Language. Educational Technology \& Society, 16(4), 146-159. https://doi.org/10.2307/jeductechsoci.16.4.146.

Praba, L. T., Artini, L. P., \& Ramendra, D. P. (2018). Project-based learning and writing skill in EFL: are they related? SHS Web of Conferences (Vol. 42, p. 00059). https://www.shsconferences.org/articles/shsconf/abs/2018/03/shsconf_gctale2018_00059/shsconf_gctale2018_ 00059.html.

Putra, F. Y., Nurkholifah, I., Subali, B., \& Rusilowati, A. (2018). 5E-Learning Cycle Strategy: Increasing Conceptual Understanding and Learning Motivation. Jurnal Ilmiah Pendidikan Fisika Al-BiRuNi, 7(2), 171-181. https://doi.org/10.24042/jipfalbiruni.v7i2.2898.

Wongdaeng, M., \& Hajihama, S. (2018). Perceptions of project-based learning on promoting 21st century skills and learning motivation in a Thai EFL setting. Journal of Studies in the English Language, 13(2), 158-190. https://so04.tci-thaijo.org/index.php/jsel/article/view/113931. 